secondary tendon repair. The film shows the suture technique intraoperatively and postoperative radiological and clinical function tests.

Key words: New tendon suture - Steel wire - Tendon suture without immobilization.

Zusammenfassung. Unter Berücksichtigung der neuesten Forschungsergebnisse über die Sehnenheilung wurde die übungsstabile Sehnennahttechnik entwickelt. Diese Technik erlaubt direkt postoperative Bewegungsübungen ohne starre Verbände, was sich positiv auf die Heilung auswirkt und Adhäsionen verhindert. Diese neue Methode ist für die primäre wie sekundäre Sehnenwiederherstellung geeignet. Der Film zeigt die Nahttechnik intraoperativ, sowie postoperative röntgenologische und klinische Funktionsprüfungen.

Schliisselwörter: Neue Sehnennaht - Sehnennaht mit Stahldraht - Sehnennaht ohne Ruhigstellung.

\title{
331. Kraftbestimmung bei externer Kompressionsosteosynthese am Frakturspalt des Menschen
}

\author{
K. H. Müller und H. W. Conradi \\ Chirurgische Klinik und Poliklinik der Berufsgenossenschaftlichen Krankenanstalten „Bergmannsheil“ \\ Bochum, Universitätsklinik, Hunscheidstraße 1, D-4630 Bochum
}

\section{Measurements of Force in External Compression Osteosynthesis in Fracture Gaps}

Summary. The film shows that in external osteosynthesis at sites of stable pressure, forces adjoining the fracture gap can be measured if there is no bending moment in the whole system. Replaceable, permanently available ring dynometers have been developed as measuring instruments on the principle of dilation measuring strips. Without changing the ASIF system, it is possible to check the force in the fracture gap during installation and throughout the healing process as well as to correct obvious dysfunctions. The measuring procedures are demonstrated on a model and two patients. The measurement of force in external fixation osteosynthesis is an important contribution to basic clinical research and a measuring instrument for fracture healing.

Key words: Measuring technique of external osteosynthesis - Replaceable ring dynometer - Objective process control.

Zusammenfassmg. Der Film zeigt, daß bei externer Osteosynthese einer druckstabilen Frakturzone die am Bruchspalt anliegenden Kräfte gemessen werden können. Voraussetzung ist eine biegemomentfreie Kraftverteilung im Gesamtsystem. Als Meßinstrumente auf dem Prinzip der Dehnungsmeßstreifen wurden abnehmbare, dauernd verfügbare Ringkraftaufnehmer entwickelt. Ohne das AO-System zuändern ist es möglich, die Kraft am Bruchspalt während der Montage und über den gesamten Heilverlauf der externen Osteosynthese meßkontrolliert zu verfolgen, sowie erkennbare Störungen zu beheben. Die Handhabung der Meßvorgänge wird sowohl am Modell als auch an 2 Patienten vorgestellt. Die Kraftmessung bei Fixateur externe-Osteosynthese erweist sich als ein Beitrag zur Grundlagenforschung und als Meßinstrument der Frakturheilung.

Schliisselwörter: Meßtechnik externer Osteosynthese - Abnehmbare Ringkraftaufnehmer - Objektive Verlaufskontrolle.

\section{Akute tiefe Venenthrombose - chirurgische Therapie}

\section{S. Hutschenreiter und J. F. Vollmar}

Department für Chirurgie der Universität Ulm, Klinik für Thorax- und Gefäßchirurgie (Ärztlicher Direktor: Professor Dr. J. Vollmar), Steinhövelstraße 5, D-7900 Ulm

\section{Acute Deep Phlebothrombosis - Surgical Therapy}

Summary. In the last 10 years late results of venous thrombectomy have been improved considerably by a standardized surgical technique, the simultaneous use of balloon catheter and ring stripper in combination with routine intraoperative vascular endoscopy of the iliac veins and a temporary arteriovenous fistula. This film demonstrates the handicaps of venous surgery and discusses the indication for venous thrombectomy. The 